\title{
SITUS BESOLE: SISA-SISA PINTU GERBANG DARI MASA KADIRI
}

\author{
Kuswanto \\ (Staf Balai Pelestarian Peninggalan Purbakala Trowulan)
}

\begin{abstract}
Besole is a site wher remants of a brick gateway were found. This site is assumed to be dated from Kadiri Kingdom period (1041 AD - 1222 $\mathrm{AD}$ ), though it exists in Blitar district. The gateway is an important element in a building complex or a city. The existence of a gateway can show the complexity of the neighbourhood. This article will discuss about the invention, rescue, and interpretation of the remmants in Besole as a contribution to reconstruct the nation civilization history.
\end{abstract}

Key words: Situs Besole, pintu gerbang, kerajaan Kadiri, wilayah Blitar

\section{PENDAHULUAN}

Kerajaan Kadiri (sekarang: Kediri) mulai muncul setelah raja Airlangga membagi kerajaannya menjadi dua yaitu Panjalu dan Jenggala pada tahun 963 Ç (1041 M) untuk dua orang putranya. Kerajaan Panjalu diberikan kepada Samarawijaya dan Kerajaan Jenggala untuk Mapanji Garasakan. Kedua kerajaan ini dibatasi oleh Gunung Kawi dan Sungai Brantas. Kerajaan Jenggala meliputi daerah Malang dan delta Sungai Brantas dengan ibukotanya di Kahuripan dan pelabuhannya di Surabaya, Rembang, dan Pasuruan. Kerajaan Panjalu yang kemudian dikenal dengan Kadiri meliputi daerah Kediri dan Madiun dengan ibukota di Daha atau Kediri sekarang (Poesponegoro, 1992: 257 - 265).

Mapanji Garasakan tampaknya berambisi untuk menguasai seluruh kerajaan ayahnya sehingga ia menyerang Kerajaan Panjalu. Garasakan diperkirakan dapat mengalahkan Kerajaan Panjalu karena untuk waktu yang relatif lama nama Panjalu tidak ditemukan dalam prasasti-prasasti yang berasal dari masa itu.

Kerajaan Kadiri tampil kembali ke panggung sejarah pada tahun 1038 Ç (1116 M) dengan ditemukannya prasasti Padlegan I dari raja Bameswara. Pemerintahan raja Bameswara berlangsung hingga tahun 1056 Ç (1134 M). Selanjutnya Kerajaan Kadiri diperintah oleh raja Jayabhaya sampai tahun 1079 Ç (1157 M). Dua tahun kemudian muncul raja Sri Sarwweswara yang memerintah Kadiri selama sekitar sepuluh tahun yang kemudian diganti oleh Sri Aryyeswara. Raja Sri Aryyeswara tidak lama memerintah karena pada tahun 1103 Ç (1181 M) telah diganti oleh Sri 
Gandra. Setahun kemudian muncul raja Sri Kameswara yang memerintah Kadiri sampai tahun 1107 Ç (1185 M). Setelah itu Kadiri diperintah oleh raja Kertajaya. Kerajaan Kadiri mulai meredup ketika raja Kertajaya dikalahkan oleh Ken Arok dari Singasari pada tahun 1144 Ç (1222 M) sehingga pusat pemerintahan pindah ke Singasari (Poesponegoro, 1992: 265 - 278).

Pada masa kerajaan Kadiri banyak dikarang atau disalin kitab-kitab kesusastraan oleh para pujangga yang sering disebut empu. Kitab-kitab yang digubah pada masa Kadiri antara lain Kakawin Kresnayana karya empu Triguna yang selesai dibuat tahun 1026 Ç (1104 M) pada masa raja Warsajaya. Kakawin Sumanasantaka karya empu Monaguna digubah pada masa raja Warsajaya. Kemudian Kakawin Smaradahana karya empu Dharmaja dibuat pada masa raja Kameswara. Kakawin Bhomakawya penulisnya tidak jelas diperkirakan sejaman dengan Kakawin Smaradahana. Kemudian Kakawin Bharatayudha digubah oleh empu Sedah dan dilanjutkan empu Panuluh pada tahun 1097 Ç (1157 M) di masa raja Jayabaya. Kakawin Hariwangsa digubah oleh empu Panuluh pada masa Raja Jayabaya. Selanjutnya ada Kakawin Gatotkacasraya karya empu Panuluh pada masa Raja Jayakreta/Kretajaya. Kakawin Wrettasancaya karya empu Tanakung pada masa akhir kerajaan Kadiri (Poerbotjaraka: 1734).

Banyaknya kitab kesusastraan yang digubah pada masa Kadiri menunjukkan bahwa tata masyarakat jaman Kerajaan Kadiri sudah tergolong maju. Kemajuan pada bidang kesusastraan tentu juga dapat menunjukkan tingginya peradaban masyarakat pada waktu itu. Masyarakat yang berperadaban tinggi seharusnya mempunyai tata kota dan bangunan yang monumental. Namun, belum banyak ditemukan tinggalan monumental dari Kerajaan Kadiri yang dapat menunjukkan kebesaran dan ketinggian peradabannya. Temuan situs Besole yang diperkirakan berasal dari masa Kerajaan Kadiri tentu menarik untuk dibahas sebagai sumbangan terhadap interpretasi dan rekonstruksi sejarah peradaban Kerajaan Kadiri.

\section{RIWAYAT DAN LINGKUNGAN SITUS}

\section{A. Riwayat Situs}

Penamaan Situs Besole didasarkan pada nama tempat situs itu diketemukan, yaitu di Dukuh Besole. Situs ini ditemukan pada tanggal 15 April 2006 oleh Bapak Sayuti (65 th) seorang petani dari Dukuh Besole, Desa Darungan, Kecamatan Kademangan, Kabupaten Blitar. Proses penemuannya terjadi ketika ia menggali tanah untuk kolam ikan di kebunnya. Pada kedalaman sekitar 1,5 meter ia menemukan bata berukuran besar (bata kuna). Karena ketidaktahuannya, penggalian kolam ikan ini terus dilakukan, bahkan sebagian struktur bata telah diangkat ke permukaan. Setelah beberapa hari Bp. Sayuti melakukan penggalian ternyata struktur bata itu terus melebar dan menemukan pula balok-balok batu candi. 
Bapak Sayuti merasakan ada keanehan dengan temuan tersebut, maka ia kemudian melaporkannya ke aparat desa setempat dan diteruskan ke Dinas Informasi Publik dan Pariwisata Kabupaten Blitar. Setelah melakukan peninjauan ke lokasi penemuan, Dinas Informasi Publik dan Pariwisata Kabupaten Blitar melaporkan temuan itu ke Balai Pelestarian Peninggalan Purbakala Trowulan Wilayah Kerja Propinsi Jawa Timur (BP3 Jatim).

Pada tanggal 10 Mei 2006 petugas dari BP3 Jatim melakukan peninjauan ke lokasi penemuan. Berdasarkan hasil peninjauan diketahui bahwa struktur bata yang ditemukan di kebun Bp. Sayuti diperkirakan merupakan bekas struktur bangunan. Struktur bangunan yang telah ditampakkan oleh penemu berukuran $5,8 \mathrm{~m} \times 5,8 \mathrm{~m}$ dengan tinggi $1,6 \mathrm{~m}$, berdenah persegi panjang dengan penampil di sisi utara dan selatan dan di sisi barat terdapat undakan tangga naik. Permukaan teratas dari temuan itu berada $\pm 180 \mathrm{~cm}$ dari permukaan tanah sekitar. Dari hasil peninjauan diketahui bahwa beberapa bagian dari struktur tersebut masih terpendam.

Sebagai langkah awal dalam upaya pelestarian terhadap situs Besole, maka BP3 Jatim pada tanggal 23 - 29 Nopember 2006 melakukan ekskavasi penyelamatan tahap I. Dari ekskavasi penyelamatan dapat diungkap sebagian besar temuan struktur bata sehingga diketahui bentuknya secara lebih lengkap. Temuan struktur bata diperkirakan merupakan bekas bangunan pintu gerbang karena terdapat anak tangga di sisi barat dan terdapat penampil di sisi kanan - kiri (utara dan selatan). Kecuali itu dalam test pit di sebelah utara situs ditemukan adanya struktur bata yang diperkirakan bagian dari pagar.

Pada tanggal $8-16$ Mei 2008 BP3 Jatim kembali melakukan ekskavasi penyelamatan tahap II di situs Besole. Sasaran ekskavasi penyelamatan tahap II diarahkan pada temuan struktur bata yang diperkirakan bagian pagar di sebelah utara bangunan yang sebagian telah ditampakkan dalam ekskavasi penyelamatan tahap I. Kegiatan ekskavasi penyelamatan tahap II selain menampakkan sebagian besar struktur bata bagian pintu gerbang, juga berhasil menampakkan struktur bata yang diperkirakan pagar yang mengarah ke utara agak serong ke timur laut.

\section{B. Letak dan Lingkungan Situs}

Situs Besole secara administratif terletak di Dukuh Besole, Desa Darungan, Kecamatan Kademangan, Kabupaten Blitar. Lokasi situs dari kota Blitar bejarak $\pm 8 \mathrm{~km}$, dapat ditempuh melalui jalan raya Blitar Kademangan, setelah melewati jembatan sungai Brantas belok ke kiri hingga melewati pasar Kademangan, selanjutnya belok ke kiri menuju ke arah Lodaya (Kecamatan Sutojayan). Setelah sampai di perempatan Desa Darungan belok ke kiri menyusuri jalan beraspal menuju ke arah Dukuh Besole, hingga sampai di perempatan jalan, kemudian lurus menyusuri jalan tidak beraspal $\pm 200 \mathrm{~m}$.

Lingkungan situs merupakan kebun yang berada di pinggir sawah. Batas situs di sebelah utara terdapat rumah milik penemu, sebelah timur 
merupakan jalan desa dan perkampungan (rumah-rumah penduduk). Sebelah selatan berupa sawah dan rumah penduduk, serta sebelah barat merupakan ladang hingga sampai ke tepi Sungai Brantas.

Daerah sekitar situs bertopografi relatif landai, merupakan bekas luapan aliran Sungai Brantas yang sekarang berada $\pm 100 \mathrm{~m}$ di sebelah utara dan membelok di sebelah barat situs. Permukaan tanahnya berupa pasir laharik dari letusan Gunung Kelud dan Gunung Semeru yang diperkirakan terangkut melalui Sungai Brantas. Vegetasi di lingkungan situs berupa kebun dan sawah yang ditanami padi, kacang, ketela pohon, dan pisang. Tumbuhan lain yang tumbuh di sekitar situs berupa pohon randu, mangga, kelapa, nangka, jati, waru, rambutan, ilalang, dan rerumputan.

\section{Deskripsi Situs}

Situs Besole diperkirakan merupakan bekas struktur bangunan yang terpendam oleh aliran lahar dari letusan Gunung Kelud melalui luapan Sungai Brantas. Bangunan situs Besole berada $\pm 180 \mathrm{~cm}$ di bawah permukaan tanah saat ini yang berupa tanah pasir laharik (tanah aluvial). Kemudian sekitar $100 \mathrm{~m}$ di sebelah utara situs mengalir Sungai Brantas yang membelok di sebelah barat situs terus ke arah barat.

Setelah dilaksanakan dua kali ekskavasi penyelamatan di situs Besole telah dapat ditampakkan sebagian besar struktur bangunan yang diperkirakan sebagai sisa-sisa bangunan pintu gerbang (gapura). Dugaan itu didasarkan pada adanya temuan tujuh anak tangga naik pada sisi barat bangunan dan adanya temuan struktur bata membujur timur laut - barat daya yang diperkirakan sebagai pagar pada sebelah utara bangunan. Kecuali itu penggalian ini juga telah berhasil menemukan adanya penampil bangunan di sisi kanan - kiri bangunan. Dalam penggalian di sebelah timur atau bagian belakang bangunan tidak ditemukan adanya tangga.

Sisa-sisa bangunan yang sudah tampak secara umum berukuran $6,5 \mathrm{~m} \times 6 \mathrm{~m}$ dan tinggi $1,64 \mathrm{~m}$. Denah berbentuk persegi empat dengan penampil di sisi utara dan selatan, serta di sisi barat terdapat tujuh (7) undakan tangga menurun ke arah barat. Di kanan-kiri undakan tangga terdapat pipi tangga dengan ujung depan berbentuk ukel melengkung ke atas. Kemudian di sisi utara bersambung dengan penampil bangunan ditemukan struktur bata yang diperkirakan pagar atau turap bangunan dengan tinggi $147 \mathrm{~cm}$, tebal $70 \mathrm{~cm}$ dan panjang yang sudah terlacak sekitar $10 \mathrm{~m}$. Struktur bata bagian pagar masih terus berlanjut ke timur laut masuk ke bagian bawah rumah penduduk. Selain itu, pada lokasi situs juga ditemukan balok-balok batu candi polos tanpa hiasan, berada di lapisan atas tiap-tiap anak tangga naik. Balok-balok batu candi tersebut telah diangkat ke permukaan oleh penemu.

Di sebelah selatan situs Besole berjarak sekitar 300 m ditemukan prasasti Besole berangka tahun 1054 Ç atau 1051 Ç. Prasasti Besole terbuat dari batu andesit berukuran tinggi $167 \mathrm{~cm}$, lebar $84 \mathrm{~cm}$, tebal 25,5 $\mathrm{cm}$. Kondisi prasasti masih utuh berbentuk balok pipih kurawal ke atas, tetapi sebagian besar tulisannya sudah aus. Pada setiap sisi permukaan 
prasasti tampaknya terdapat tulisan beraksara Jawa Kuna, tetapi sudah banyak yang aus sehingga tidak terlihat jelas. Bagian lapik prasasti tampak terpendam dalam tanah. Prasasti ini terletak di dekat kandang kambing di belakang rumah $\mathrm{Bp}$. Dasar (ahli waris almarhum Bp. Mulyani).

\section{INTERPRETASI BENTUK BANGUNAN DAN KRONOLOGI SITUS BESOLE}

\section{A. Bentuk dan Fungsi Bangunan}

Ekskavasi penyelamatan situs Besole telah dapat menampakkan sebagian dari struktur bangunan yang diperkirakan merupakan sisa-sisa bangunan pintu gerbang (gapura). Hal itu didasarkan pada temuan undakan tangga naik di sisi barat bangunan yang di sisi kanan-kirinya terdapat pipi tangga, serta adanya temuan struktur di sebelah utara bangunan yang diperkirakan bagian pagar. Pintu gerbang merupakan bangunan yang memiliki fungsi sebagai pintu pada suatu kompleks. Pintu gerbang umumnya menyatu dengan pagar, walaupun ada juga yang berdiri sendiri. Jenis pintu gerbang ada dua, yaitu yang tidak beratap disebut bentar dan yang mempunyai atap disebut paduraksa. Tipe bentar merupakan pintu gerbang yang mengambil bentuk bangunan candi dibelah dua (split gate) tanpa atap, sedangkan paduraksa merupakan pintu gerbang yang mengambil bentuk bangunan candi dengan sebuah pintu di tengahnya (Atmodjo, dkk., 1998/1999: 12).

Sisa-sisa bangunan di situs Besole memang sudah tidak utuh lagi, diperkirakan hanya tinggal bagian kaki bangunan. Walaupun demikian masih dapat dikenali bahwa bangunan tersebut merupakan bekas bangunan pintu gerbang. Ciri bangunan pintu gerbang yang masih melekat berupa pipi tangga yang mengapit jenjang anak tangga dan sambungan dinding pagar/turap (Munandar, 2003: 90-109). Ciri bangunan pintu gerbang lain seperti bagian tubuh, "sayap" samping, dan atap sudah tidak ditemukan pada bangunan situs Besole. Sementara itu pada sisi timur/belakang bangunan tidak ditemukan adanya anak tangga. Berdasarkan bentuk bangunan yang telah ditampakkan maka diperkirakan bangunan pintu gerbang ini dibangun pada tanah yang tidak rata, tetapi miring ke arah barat, sehingga tangga hanya diperlukan pada bagian barat/depan. Permukaan tanah bagian belakang tampaknya sejajar dengan lantai pintu gerbang sehingga tidak diperlukan tangga.

Pada sisi kanan-kiri bangunan pintu gerbang ditemukan adanya struktur bata yang diperkirakan sebagai pagar sekaligus turap halaman. Hal itu dibuktikan dengan hasil ekskavasi di sebelah utara bangunan pintu gerbang yang menemukan dinding bata dengan sisi sebelah barat (depan) disusun rapi dan berprofil, sedangkan sisi sebelah timur (belakang) dengan permukaan dinding tidak rata. Perbedaan penyelesaian akhir (finishing) permukaan dinding pagar tersebut menunjukkan bahwa bagian depan memang sengaja ditampakkan, sedangkan bagian belakang tidak 
ditampakkan (ditutup tanah) sehingga tidak harus dirapikan. Perbedaan ini juga menunjukkan bahwa permukaan tanah asli di depan pintu gerbang memang lebih rendah dari permukaan tanah di belakang pintu gerbang. Permukaan sisi belakang dinding pagar/turap tidak perlu dibuat rapi/rata karena akan tertutup oleh tanah yang permukaannya lebih tinggi dari permukaan tanah di bagian depan dinding pagar/turap.

Fungsi sisa-sisa bangunan pintu gerbang ini belum dapat diketahui secara pasti. Bisa jadi sebagai pintu keluar-masuk, tetapi belum ditemukan indikasi temuan lain di sekitar situs, sehingga tidak dapat dipastikan apakah bangunan ini merupakan pintu masuk ke suatu kompleks bangunan atau ke suatu wilayah (kota). Akan tetapi berdasarkan temuan pagar/turap di sebelah utara bangunan, dapat diperkirakan pintu gerbang tersebut adalah pintu masuk ke suatu bangunan atau ke halaman kompleks bangunan. Perkiraan ini didasarkan pada ukuran pagar/turap yang relatif kecil, yaitu tinggi $147 \mathrm{~cm}$ dan tebal $70 \mathrm{~cm}$, sehingga terlalu kecil sebagai pagar kota (benteng).

Berdasarkan lokasi situs yang dekat dan menghadap ke arah sungai Brantas, hanya berjarak $\pm 100 \mathrm{~m}$, dimungkinkan bangunan ini merupakan pintu gerbang yang mengarah ke sungai. Mungkin saja ke suatu "pelabuhan" kuna di pinggir sungai Brantas. Berdasarkan bentuk turap yang relatif pendek, diperkirakan bangunan situs Besole dapat juga berbentuk semacam batur dengan salah satu pintu masuknya berada di sebelah barat. Perkiraan ini masih harus dibuktikan dengan penemuan sudut pagar/turap yang masih sulit direalisasikan karena bagian pagar/turap masih terus berlanjut ke arah utara masuk di bawah rumah penduduk.

\section{B. Kronologi Situs Besole}

Penentuan umur situs Besole kiranya dapat dihubungkan dengan prasasti Besole yang pernah ditemukan di Dukuh Besole, Desa Darungan, Kecamatan Kademangan, Kabupaten Blitar. Prasasti Besole dipahatkan pada balok batu beraksara dan berbahasa Jawa Kuna, tetapi kondisi hurufnya sudah sangat aus sehingga sulit dibaca. Pada bagian depan terpahat candra kapala lañcana dan angka tahun $1054 \mathrm{Ç}$ atau $1051 \mathrm{C}$, sedangkan pada bagian belakang terbaca rumakşa praja (baris 2) dan cakrawartin (baris 3). Menilik angka tahun dan bentuk hurufnya maka diduga Prasasti Besole berasal dari masa Kadiri, yaitu masa Raja Bameswara yang memerintah antara tahun 1038 Ç sampai dengan 1056 Ç (Suhadi, 1996: 24). Informasi lain dari prasasti ini belum dapat diungkap karena tulisannya sudah aus. Prasasti Besole ditemukan sekitar $300 \mathrm{~m}$ di sebelah selatan dari situs Besole sehingga keberadaannya diperkirakan masih satu konteks dengan situs Besole.

Prasasti Besole sebenarnya dapat digunakan sebagai acuan untuk menentukan perkiraan umur dari sisa-sisa bangunan pintu gerbang di situs Besole, tetapi sayang semua tulisannya belum dapat terbaca. Angka tahun 1054 Ç (1132 M) atau 1051 Ç (1129 M) yang berhasil dibaca dari prasasti Besole menunjukkan bahwa daerah Dusun Besole (Desa Darungan) dan 
sekitarnya sudah eksis pada masa Raja Bameswara. Sebenarnya, apabila prasasti Besole dapat dibaca lebih lengkap, tentu akan banyak informasi yang diperoleh tentang masa lalu daerah Besole dan sekitarnya.

Raja Bameswara rupanya memang sangat memperhatikan daerah Blitar dan sekitamya. Terbukti, beberapa prasastinya ditemukan di daerah Blitar. Selain prasasti Besole ditemukan prasasti Pandelegan I di Desa Pikatan, Kecamatan Srengat, Kabupaten Blitar yang dikeluarkan oleh Raja Bameswara pada tanggal 11 Januari 1117. Prasasti Pandelegan I berisi tentang anugerah Raja Bameswara kepada penduduk Desa Pandelegan. Prasasti ini memberikan status swatantra dan pembebasan pajak kepada penduduknya yang telah ikut memajukan perniagaan sehingga menambah pemasukan pendapatan raja (Tim, 1976: 23).

Selain itu, ada juga prasasti Panumbangan yang ditemukan di halaman candi Plumbangan, Desa Plumbangan, Kecamatan Doko, Kabupaten Blitar. Prasasti ini dikeluarkan oleh Raja Bameswara pada tanggal 2 Agustus $1120 \mathrm{M}$ dan berisi tentang pemberian status swatantra kepada penduduk Desa Panumbangan. Desa Panumbangan yang dimaksud dalam prasasti ini mungkin sekali sekarang berubah nama menjadi Desa Plumbangan (Tim, 1976: 25).

Temuan tiga buah prasasti Raja Bameswara di daerah Blitar menunjukkan bahwa wilayah Blitar pada masa itu merupakan daerah permukiman yang sudah ramai. Bukti adanya permukiman dengan jumlah penduduk yang signifikan di daerah Blitar pada masa itu yaitu adanya Candi Plumbangan. Adanya candi ini mengindikasikan bahwa di sekitarnya terdapat komunitas yang mendukung keberadaan bangunan candi itu. Kecuali itu, Desa Pikatan di Kecamatan Srengat tempat ditemukannya prasasti Pandelegan I juga relatif dekat dengan situs Besole berjarak sekitar $8 \mathrm{Km}$. Oleh karena itu sangat dimungkinkan prasasti Besole merupakan anugerah dari Raja Bameswara berkenaan dengan adanya bangunan atau kompleks bangunan di situs Besole.

Apabila melihat ukuran bata di Situs Besole yang masif (besar) dengan pemasangan tanpa spesi (sistem kosod) serta bentuk bangunannya, khususnya bentuk ujung pipi tangga yang berbentuk ukel (melengkung ke atas), diperkirakan bangunan ini berasal dari Masa Majapahit. Hal itu juga didukung kenyataan bahwa di sekitar lokasi temuan, khususnya di wilayah Kecamatan Kademangan dan sekitarnya, banyak terdapat peninggalan purbakala dari Masa Majapahit. Sekitar $5 \mathrm{~km}$ di sebelah utara lokasi temuan terdapat kumpulan arca Gaprang di Desa Gaprang, Kecamatan Kanigoro. Menurut catatan Belanda di Dukuh Djimbe, Desa Kademangan, Kecamatan Kademangan sekitar $5 \mathrm{~km}$ di sebelah barat lokasi temuan pemah ditemukan batu-batu candi. Batu-batu candi itu ada yang berhias kala, cakra, dan trisula serta ada yang berangka tahun Jawa Kuno 1314 Ç atau 1392 M (Knebel, 1908: 137).

Kemudian sekitar $5 \mathrm{~km}$ di barat daya lokasi temuan terdapat peninggalan kepurbakalaan Candi Simping di Desa Sumberjati, Kecamatan Kademangan. Candi Simping merupakan candi pemujaan untuk Raden 
Wijaya, pendiri Kerajaan Majapahit. Kitab Nagarakretagama mengisahkan peristiwa pemugaran Candi Simping yang dilakukan oleh Raja Hayam Wuruk karena sebagian candi telah rusak.

Berdasarkan berita dari kitab Nagarakretagama dapat diketahui bahwa daerah Blitar merupakan daerah yang penting pada masa Kerajaan Majapahit. Hal itu terbukti dengan adanya tiga kali kunjungan Raja Hayam Wuruk ke daerah Blitar. Di samping itu, di wilayah Blitar banyak ditemukan bangunan-bangunan suci yang berasal dari masa Majapahit. Dalam Nagarakretagama tercatat beberapa tempat di wilayah Blitar yang pernah dikunjungi oleh Raja Hayam Wuruk seperti termuat dalam Pupuh XVII: 6 sebagai berikut;

- Tahun Aksatisurya (1275) sang prabu menuju Pajang membawa banyak pengiring

- Tahun Saka angga naga aryama (1276) ke Lasem, melintasi pantai samudera

- Tahun Saka pintu gunung mendengar indu (1279) ke laut selatan menembus hutan

- Lega menikmati pemandangan alam indah Lodaya, Tetu, dan Sideman (Mulyana, 1979: 282).

berikut;

Dalam Nagarakretagama Pupuh LXI: 2 - 4 dinyatakan sebagai

2. Tahun Saka tiga badan dan bulan (1283) Waisaka

Baginda raja berangkat menyekar ke Palah

Dan mengunjungi Jimbe untuk menghibur hati

Di Lawang Wentar, Blitar menentramkan cita

3. Dari Blitar ke selatan jalannya mendaki

Pohonnya jarang, layu lesu kekurangan air

Sampai Lodaya bermalam beberapa hari

Tertarik keindahan lautan menyisir pantai

4. Meninggalkan Lodaya menuju Desa Simping

Ingin memperbaiki candi makam leluhur

Menaranya rusak dilihat miring ke barat

Perlu ditegakkan kembali agak ke timur (Mulyana, 1979: 304)

Jimbe, Lawang Wentar, Blitar, dan Simping semua menunjuk pada beberapa tempat di Kabupaten Blitar. Desa Jimbe berada di wilayah Kecamatan Kademangan berjarak sekitar $5 \mathrm{~km}$ dari situs Besole. Lawang Wentar sekarang menjadi Sawentar tempat berdirinya Candi Sawentar I, sedangkan Candi Sawentar II berada di Kecamatan Kanigoro berjarak sekitar $7 \mathrm{Km}$ dari Situs Besole. Candi Simping sekarang termasuk dalam wilayah Desa Sumberjati, Kecamatan Kademangan yang merupakan bangunan candi pendharmaan dari Raden Wijaya, pendiri Majapahit. Pada pupuh LXX: 1 juga diberitakan bahwa Raja Hayam Wuruk kembali mengunjungi daerah Simping, isi selengkapnya adalah sebagai berikut. 


\section{Tersebut pada tahun Saka angin delapan utama (1285)}

Baginda menuju Simping demi pemindahan candi makam

Siap lengkap segala persajian tepat menurut adat

Pengawasnya Rajaparakrama memimpin upacara (Mulyana, 1979: 309).

Mengacu pada berita Nagarakretagama yang memuat beberapa nama daerah di wilayah Kabupaten Blitar tampak bahwa daerah yang terdekat dengan situs Besole adalah Lodaya. Sekitar $3 \mathrm{Km}$ di sebelah timur situs Besole ditemukan prasasti Jaring yang berada di Dusun Jaring, Desa Kembangarum, Kecamatan Sutojayan. Prasasti Jaring berangka tahun 1103 Ç atau $1181 \mathrm{M}$ dikeluarkan oleh raja Sri Gandra dari kerajaan Kadiri.

\section{Penyebab Kerusakan Situs}

Penyebab utama kerusakan situs Besole diperkirakan adalah luapan lahar dingin dari Sungai Brantas yang terletak sekitar $100 \mathrm{~m}$ di sebelah utara dan barat situs. Berdasarkan pengamatan stratigrafi tanah dari hasil galian yang sudah ditampakkan, deposit di situs Besole merupakan lapisan tanah pasir laharik $( \pm 200 \mathrm{~cm}-300 \mathrm{~cm}$ ). Stratigrafi lapisan tanah terdiri dari 10 lapisan sebagian besar berupa lapisan pasir halus sampai kasar dan diselingi lapisan tanah lempung pasiran. Oleh karena itu bangunan ini diperkirakan runtuh dan terkubur oleh aliran lahar dari letusan gunung pada masa lalu, mungkin Gunung Kelud. Berdasarkan lapisan tanah hasil penggalian tampak bahwa lapisan pasir laharik tersebut berlapis-lapis sehingga diperkirakan berasal dari beberapa kali letusan gunung. Mengenai adanya letusan gunung di masa lalu diperoleh keterangan dari kitab Pararaton, kitab ini menyebutkan bahwa pada masa Majapahit pernah terjadi beberapa kali gunung meletus, seperti di tahun $1233 \mathrm{C}(1311 \mathrm{M})$, 1307 Ç (1385 M), 1317 Ç, (1395 M), 1343 Ç (1421 M), 1373 Ç (1451 M), 1384 Ç (1462 M), dan 1403 Ç (1481 M) (Pitono, 1965: 48-59). Sehingga keterangan dari kitab Pararaton tersebut sesuai dengan kondisi lapisan pasir laharik yang ditemukan di situs ini.

Berdasarkan hasil penelitian yang pernah dilakukan memang lapisan tanah bekas aliran lahar dari letusan gunung Kelud pernah mengubur situssitus kepurbakalaan di Kabupaten Blitar. Misalnya, lapisan pasir laharik juga pernah mengubur situs Sawentar II di Dukuh Centong, Desa Sawentar, Kecamatan Kanigoro. Menurut penelitian dari Balai Arkeologi Yogyakarta, diketahui bahwa tanah asli (maaiveld) Candi Sawentar II berada antara 130 $\mathrm{cm}-200 \mathrm{~cm}$ dari permukaan tanah sekarang (Tjahjono, 2000: 36). Dengan demikian tidaklah mengherankan jika tanah maaiveld situs Besole juga berada $\pm 300 \mathrm{~cm}$ dari permukaan tanah sekitar. Hal itu juga didukung oleh keletakan situs yang berada di pinggir Sungai Brantas sehingga pengaruh aktivitas laharik sangat besar pada situs ini.

Sementara itu data aktivitas letusan Gunung Kelud juga tercatat dalam buku "Dasar Gunung Berapi di Indonesia" (Direktorat Vulkanologi: 1980). Berdasarkan catatan itu diketahui bahwa hingga tahun 1992 Gunung Kelud telah mengalami erupsi sebanyak 31 kali, yaitu terjadi pada tahun: 
$1000 ; 1311 ; 1334 ; 1376 ; 1385 ; 1395 ; 1411 ; 1451 ; 1462 ; 1481 ; 1548 ; 1586$; $1641 ; 1716$; 1752; 1771; 1776; 1785; 1811; 1825; 1826; 1835; 1848; 1851; $1864 ; 1901 ; 1919 ; 1920 ; 1951 ; 1966$; dan 1990. Bahkan diduga letusan Gunung Kelud sudah berlangsung sebelum tahun 1000 Masehi dan terjadi beberapa kali letusan sampai tahun 1992. Jika catatan tersebut dapat diandalkan, maka terdapat satu masa yang cukup panjang ketika Gunung Kelud tidak meletus lagi (masa istirahat) yaitu antara tahun $1000 \mathrm{M}$ dan 1311 M. Masa tersebut dalam sejarah merupakan jaman Kerajaan Kahuripan (Airlangga) yang berlangsung tahun 1019-1045 M, dilanjutkan jaman kerajaan Kadiri yang berlangsung tahun 1045-1222 M, hingga masa akhir kerajaan Singasari (1222 M - $1292 \mathrm{M}$ ), dan awal kerajaan Majapahit (1293 M).

Interval masa yang cukup lama antara tahun $1000 \mathrm{M}$ sampai $1311 \mathrm{M}$ tampaknya merupakan masa pembuatan bangunan-bangunan dari empat kerajaan tersebut. Rentang masa selama 300 tahun lebih tentu merupakan waktu yang cukup panjang sehingga pembangunan dapat dilaksanakan dengan baik, khususnya bangunan di sepanjang daerah aliran Sungai Brantas. Setelah itu Gunung Kelud meletus hingga beberapa kali dalam interval waktu yang tidak terlalu lama sehingga diperkirakan mengubur sebagian besar bangunan monumental dari masa ke-empat dinasti tersebut.

\section{PENUTUP}

Situs Besole yang berada di Dukuh Besole, Desa Darungan, Kecamatan Kademangan, Kabupaten Blitar merupakan sisa-sisa struktur bangunan dari bahan bata. Bentuk bangunan yang sudah dapat ditampakkan diperkirakan merupakan sisa-sisa bangunan pintu gerbang (gapura). Asumsi tersebut didasarkan dari adanya anak tangga yang diapit oleh pipi tangga dan adanya temuan pagar/turap bangunan di sisi utaranya.

Kronologis situs Besole diperkirakan berhubungan dengan keberadaan prasasti Besole yang berangka tahun $1051 \mathrm{C}$ (1129 M) atau 1054 Ç $(1132 \mathrm{M})$, yang dikeluarkan oleh Raja Bameswara dari Kerajaan Kadiri. Oleh karena itu bangunan di situs Besole diperkirakan sudah ada sejak jaman kerajaan Kadiri, khususnya masa raja Bameswara.

Tulisan ini merupakan pemaparan awal tentang keberadaan Situs Besole sebagai tambahan data dalam interpretasi sejarah peradaban bangsa. Kajian ini tentu masih jauh dari sempuma, oleh karena itu masih sangat perlu kajian yang lebih mendalam terhadap situs Besole. Hal itu perlu dilakukan karena situs Besole memiliki nilai penting untuk mengungkap sejarah peradaban dan eksistensi kerajaan Kadiri di daerah Blitar.

Berdasarkan kondisi situs Besole saat ini yang sebagian masih terpendam tanah maka perlu disarankan hal-hal sebagai berikut.

1. Perlu ada upaya untuk memproteksi tanah di sekitar situs agar tidak digunakan untuk aktivitas yang dapat merusak situs. 
2. Perlu tindakan pengamanan struktur yang sudah ditampakkan dengan pemberian pagar sementara dan mengangkat juru pelihara situs.

3. Perlu penelitan lebih lanjut pada situs ini karena diperkirakan masih banyak struktur bata, khususnya bagian pagar/turap yang masih terpendam tanah dan sebagian berada di bawah pondasi rumah penduduk.

4. Perlu pembebasan lahan situs sehingga nantinya bangunan di situs ini dapat ditampakkan seluruhnya.

\section{KEPUSTAKAAN}

Atmodjo, Junus Satrio, dkk. 1998/1999. Vademikum Benda Cagar Budaya. Jakarta: Proyek Pembinaan Peninggalan Sejarah dan Kepurbakalaan Pusat.

Bosch, F.D.K. 1918. Rapporten Oudheidkundigen Dients in Nederlandsch Indië 1915 (ROD 1915). Weltevreden: Albrecht \& Co. I's Gravenhage: M. Nijhoff.

Hardjowardojo, Pitono. 1965. Pararaton. Djakarta: Bhratara.

Knebel, J. 1909. Rapporten van de Commissie in Nederlandsch - Indië voor Oudheidkundig Onderzoek op Java end Madoera 1908 (ROC 1908). Batavia: Albrecht \& Co. /'s Gravenhage: M. Nijhoff.

Munandar, Agus Aris. 2003. "Tinjauan Ringkas Arsitektur Pintu Gerbang Pada Masa Hindu-Buddha di Jawa". Dalam Aksamala Bunga Rampai Karya Penelitian. Bogor: Akademia.

Poerbotjaraka, R.M.Ng dan Tarjan Hadidjaja. tt. Kepustakaan Djawa. Penerbit Djambatan.

Poesponegoro, Marwati Djoened, dkk., 1992. Sejarah Nasional Indonesia II. Jakarta: Balai Pustaka.

Suhadi, Machi dan Richadiana K. 1996. "Laporan Penelitian Epigrafi di Wilayah Provinsi Jawa Timur". Dalam Berita Penelitian Arkeologi No. 47. Jakarta: Puslitarkenas.

Sukendar, Haris., dkk. 1999-2000. Metode Penelitian Arkeologi. Jakarta: Puslitarkenas.

Tim Penggali dan Perumus Hari Jadi Kabupaten Blitar. 1976. Hari Jadi Kabupaten Blitar 5 Agustus 1324. 
Tjahjono, Baskoro Daru dan Nurhadi Rangkuti. 2000. "Candi Sawentar II di Blitar Latar Belakang Sejarah dan Lingkungannya". Dalam Berita Penelitian Arkeologi No. 11. Balar Yogyakarta.
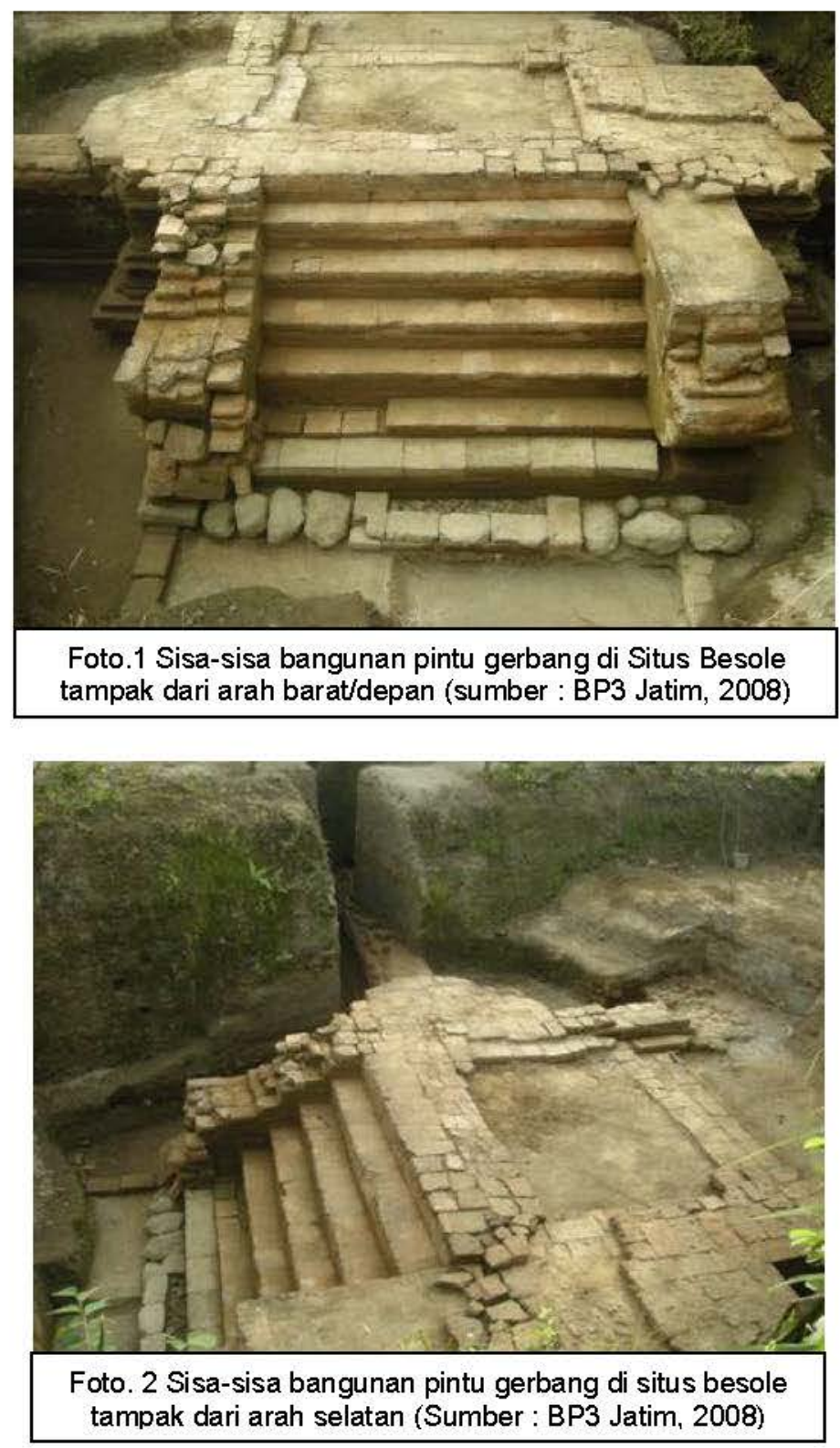